\title{
INTEGRATED MANAGEMENT OF ENVIRONMENTAL- SAFETY AND TECHNICAL RISKS OF PLANTS PRODUCING AUTOMOBILES AND AUTOMOBILE COMPONENTS
}

The authors, as a result of their scientific and professional activities, present a concept of a future model for integrated management of risks in plants for production of automobiles and their components for contractors. They introduce the concept of a future standardized model of an integrated management system based on sub-aspects, impacts and risks according to the relevant current and upcoming new ISO standards of quality, environment, safety, including ISO 31000 Risks management and ISO/TS 16949. In this article the emphasis is placed on creation of a complex risks register (technical, environmental, safety), for this area of economic activity, their identification, analysis and evaluation within an integrated management system.

Keywords: Automobile production, standardized management system, environmental and security risks, integrated management system, risks register, risk-assessment model.

\section{Introduction}

Sustainable development in automobile manufacturing is now becoming strongly associated with its environmentalization and improvement of the quality from a complex point of view.

In this context, the organizations in the network of automobile industry suppliers are also forced to integrate environmental management, safety and technical aspects, impacts and risks of its production into their management systems. With increasing pressure from the whole society and intensifying pressure on the supply-chain, an evaluation of environmental, safety and technical risks represent an innovative approach by which an enterprise can effectively mitigate environmental-security threats, as well as create competitive advantages.

As a result of scientific research activities of the authors in the area of implementation, maintenance and authorization of integrated management systems (IMS), a suggestion and verification of the methodology for evaluation of environmentalsafety and technical risks of products in automobile industry enterprises on selected products.

\section{Integrated Management System based on ISO standards in plants} for production of automobiles and their components

Ensuring the success of organizations by implementing various standardized management systems in today's difficult economic situation becomes increasingly common in general and in automobile manufacturing industry, primarily from the point of view of production complexity, quality and especially competitiveness. The best known and most frequently applied international standards include:

- Quality Management System (ISO 9001),

- Environmental Management System (ISO 14001, EMAS III),

- Occupational Health and Safety Management System (OHSAS 18001),

- Risk Management System (ISO 31000) and others.

Branch industry standards are increasingly used and an example for the investigated area is:

- Quality Management System. Particular requirements for application of ISO 9001:2008 in organizations for automobile production and their spare parts.

Currently, there is a unification of the standards structure on an internatonal level and their forthcoming revision (2015)

\footnotetext{
* ${ }^{1}$ Milan Majernik, ${ }^{1}$ Petra Szaryszova, ${ }^{1}$ Martin Bosak, ${ }^{1}$ Lenka Stofova, ${ }^{2}$ Kani Kabdi

${ }^{1}$ Department of Management, Faculty of Business Economics in Kosice, University of Economics in Bratislava, Slovakia

${ }^{2}$ L. N. Gumilyov Eurasian National University Astana, Kazachstan

E-mail: milan.majernik@euke.sk
} 
should bring unification in the form of 10 identical chapters in support of management systems integration. The concept of a standardized integrated management system model in the automobile plants industry (see Fig. 1) would create conditions for integrated management, environmental-safety and technical aspects, impacts and risks while fulfilling all requirements of submanagement systems. The basic prerequisite for the effectivity of such a system is the creation of an integrated risks register for continuous process improvement.

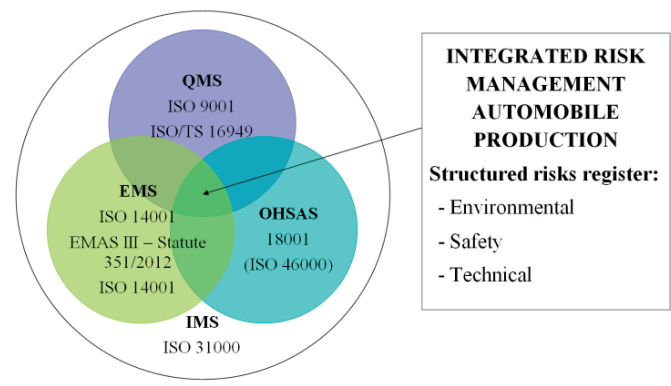

Fig. 1 Model of Integrated Management of risks in automobile industry operations

The basic guideline for the management of risks, regardless of their origin and character is the ISO 31000 standard with the only negative resulting from the fact that it is not a standard intended for certification purposes. Environmental risks will, therefore, be solved through implementation of ISO 14001 certification, or as part of the approaches of the EU, namely EMAS III. Until the Occupational Health and Safety Management ISO 46000 standard (2016) is published, it is possible to certify the system through the implementation of OHSAS 18001. The authentication of quality management according to ISO 9001 and ISO/TS 16949 remains the key element of IMS.

\section{Risk analysis of the sustainability of automobile production products}

Organizations in the network of automobile industry suppliers must continually improve the effectivity of their quality management system and manage their risks for development of sustainability. Improving of the production process must be continuously focused on management and reduction of product characteristics and manufacturing process parameters variance.

In every business, the management must decide which risks the company would be willing to accept in comparison to possible opportunities. This process can lead to a mixed strategy which everyone agrees with, and the organization is exposed face to face to uncertainty. Organization can work on reduction of their most vulnerable areas, while paying attention to their most important opportunities [1].

All approaches to risk management have a number of common basic points: to identify risks, determine the degree of hazard and to find ways to cope with them effectively. It is not important whether the concept of risk management in the enterprise is defined, but whether there are automatic tools leading to risk management control [2].

Risk management must be based on the management of the enterprise as a whole. „Effective risk management, identifying new events and changed circumstances, assists management in decision-making in the review of the company positions and its prospects“ [3].

In their work on the development and production of sustainable product, the authors emphasized the relevance of integration of environmental aspects into production of a new product and new decision-support tools to achieve it [4].

Other authors confirmed that achieving overall sustainability requires a focused look at the entire supply chain, including manufacturing systems and processes and a detailed life-cycle, which includes a better understanding of the impact of the product, predictive models of individual processes and optimized production processes, as well as optimization of all activities within a closed loop supply chain. In the development of advanced predictive models and optimization techniques for sustainable production, the authors also analyzed simplified scoring models for sustainable planning and production processes [5].

The authors of [6] proposed a new framework for assessing sustainability of business operations in the manufacturing sector, implementation of economic, environmental, safety and technical objectives into organizational operating procedures with an increasing focus on achieving sustainable business.

In their article [7], the authors presented how to compare companies with an appropriate level of sustainability using a model for designing the composite index of sustainable development, which determines efficiency and effectivity of businesses.

In comparison with different methods of integrated sustainability, the assessment methods of strategic environmental impact assessment results and, „triple-bottom-line approach“, concluded that the assessment of environmental aspects, impacts and risks requires a clear concept of sustainability as a social goal, defined criteria according to which assessments are realized and which effectively separates sustainable results from unsustainable ones [8].

\section{Research methodology}

Our research was realized on a selected production operation of the automobile industry. The risk management needs of the cable harnesses production life cycle were devided into the following 9 stages:

1. Receipt of material.

2. Transportation of the product to the warehouse.

3. Transportation by forklift.

4. Handling in the warehouse. 
5. Cutting the cables.

6. Contact, welding, soldering, cutting contacts.

7. Stripping of cables.

8. Cable formation, repairs.

9. Electrical control, packaging.

\subsection{Register of environmental-safety and technical risks}

According to the impact probability and importance of each risk, certain value was given to each of the identified risks. From all of the identified risks - actual number 97 we chose those which reached the highest value. These risks had the value in the range of 0.033 to 2.256 . Based on the prepared matrix of risk impact importance and probability (see Table 1), we deal with the risks of high importance and the relevant part of the register listing important environmental-safety and technical risks, as shown in Table 1.
From a review of literature, there is a clear need to use an assessment of environmental- safety and technological risks, but their results, as reflected in the stage of production cycle of existing products, failed to be expressed in many cases. To bridge the gap, this study aims to provide clearly set risks which have been identified and analyzed in the enterprise.

\subsection{Evaluation of environmental-safety and technical risks of production of cable harnesses}

For components or parts in finished products which meet specifications or customer expectations and are in accordance with ISO/TS 16949 (technical aspects) there is used the man machine setting with division of labor in production and defined responsibility for the quality of the processes involved. This is the correct setting of material, resource and practise planning. Once the product reaches the employees (product handling)

Part of the register listing environmental-safety and technical risks of an operation for the production of automobile harnesses

Table 1

\begin{tabular}{|c|c|c|c|c|c|c|c|c|c|c|c|c|}
\hline \multirow{2}{*}{$\begin{array}{l}\text { Organizational } \\
\text { unit / place } \\
\text { of creation }\end{array}$} & \multirow{2}{*}{$\begin{array}{c}\text { Activity / } \\
\text { process } \\
\text { of creation }\end{array}$} & \multirow{2}{*}{$\begin{array}{c}\text { Environmental } \\
\text { aspect }\end{array}$} & \multirow{2}{*}{$\begin{array}{c}\text { Environmental } \\
\text { impact } \\
\text { - pollution }\end{array}$} & \multicolumn{3}{|c|}{ Risks } & \multicolumn{3}{|c|}{$\begin{array}{c}\text { Assessing } \\
\text { the significance of }\end{array}$} & \multirow{2}{*}{ S/INS } & \multirow{2}{*}{$\mathrm{PE} / \mathrm{PO}$} & \multirow{2}{*}{$/ I N D$} \\
\hline & & & & ER & SR & TR & I & P1 & $\mathbf{P 2}$ & & & \\
\hline \multirow{5}{*}{$\begin{array}{l}\text { Warehouse } \\
\text { of logistics, } \\
\text { warehouse } \\
\text { of hazardous } \\
\text { waste }\end{array}$} & \multirow{5}{*}{$\begin{array}{l}\text { Handling } \\
\text { of } \\
\text { hazardous } \\
\text { waste } \\
\text { in storage }\end{array}$} & $\begin{array}{l}\text { Plastic } \\
\text { containers } \\
\text { containing } \\
\text { residues of } \\
\text { dangerous } \\
\text { substances } \\
\end{array}$ & $\begin{array}{l}\text { Hazardous } \\
\text { substances, } \\
\text { waste }\end{array}$ & $\begin{array}{l}\text { Toxicity } \\
\text { Landfilling }\end{array}$ & $\begin{array}{l}\text { Caustic } \\
\text { burns }\end{array}$ & $\begin{array}{c}\text { Potential } \\
\text { damage of } \\
\text { components } \\
\text { of wiring } \\
\text { harness }\end{array}$ & 3 & 0.594 & 0.527 & $\mathrm{~S}$ & $\mathrm{PE}$ & D \\
\hline & & $\begin{array}{c}\text { Metal } \\
\text { packaging }\end{array}$ & $\begin{array}{l}\text { Hazardous } \\
\text { substances, } \\
\text { waste }\end{array}$ & $\begin{array}{l}\text { Oxidation } \\
\text { Landfilling }\end{array}$ & $\begin{array}{l}\text { Capture } \\
\text { Cuts }\end{array}$ & $\begin{array}{c}\text { Potential } \\
\text { damage of } \\
\text { components } \\
\text { of wiring } \\
\text { harness }\end{array}$ & 3 & 0.403 & 0.384 & $\mathrm{~S}$ & $\mathrm{PE}$ & D \\
\hline & & $\begin{array}{l}\text { Absorbents } \\
\text { contaminated } \\
\text { by pollutants }\end{array}$ & $\begin{array}{c}\text { Hazardous } \\
\text { substances, } \\
\text { waste }\end{array}$ & $\begin{array}{c}\text { Water } \\
\text { contamination }\end{array}$ & $\begin{array}{l}\text { Caustic } \\
\text { burns }\end{array}$ & $\begin{array}{l}\text { Technical } \\
\text { failure of } \\
\text { machinery }\end{array}$ & 4 & 0.755 & 0.726 & $\mathrm{~S}$ & $\mathrm{PE}$ & D \\
\hline & & $\begin{array}{c}\text { Hazardous } \\
\text { substances, } \\
\text { solvents }\end{array}$ & $\begin{array}{c}\text { Water } \\
\text { pollution } \\
\text { hazardous } \\
\text { substances }\end{array}$ & $\begin{array}{c}\text { Water } \\
\text { contamination } \\
\text { Oxidation } \\
\text { Toxicity }\end{array}$ & $\begin{array}{c}\text { Inhalation, } \\
\text { ingestion } \\
\text { or } \\
\text { absorption } \\
\text { of } \\
\text { hazardous } \\
\text { substances } \\
\text { by skin }\end{array}$ & $\begin{array}{c}\text { Shorting or } \\
\text { breakage of } \\
\text { cable } \\
\text { harnesses }\end{array}$ & 5 & 0.839 & 0.913 & $\mathrm{~S}$ & $\mathrm{PE}$ & D \\
\hline & & Chemicals & $\begin{array}{l}\text { Hazardous } \\
\text { substances }\end{array}$ & $\begin{array}{l}\text { Acid rains } \\
\text { Greenhouse } \\
\text { Effect } \\
\text { Chemical } \\
\text { spill }\end{array}$ & $\begin{array}{c}\text { Fire } \\
\text { Damage } \\
\text { of the } \\
\text { health of } \\
\text { employees }\end{array}$ & $\begin{array}{c}\text { Damage of } \\
\text { machinery } \\
\text { deformation } \\
\text { of cable } \\
\text { harnesses }\end{array}$ & 5 & 0.871 & 0.885 & $\mathrm{~S}$ & $\mathrm{PE}$ & $\mathrm{D}$ \\
\hline
\end{tabular}

\section{Explanation:}

I - Importance

P1 - Probability of the impact on the environment

P2 - Probability of the impact on human health

ER - Environmental risk

TR - Technical risk
SR - Safety risk

S/INS - Significant / Insignificant aspect

PE/PO - Permanent / Potential aspect

D/IND - Direct / Indirect aspect 
the stage which leads to different load cases and in various degrees to negative effects on health and safety of a person or the environment begins. In the stage of handling the product uses a lot of resources, either directly or indirectly. The final stage of production and packaging of the product also requires regular inspection or, maintenance, which must be determined on the basis of a designated production program of the enterprise. An important stage of the product life cycle is the production of waste which plays a crucial role in the dynamically changing modern world and developing environmental, safety and technical standards. On that basis, we need to have answers to the following concepts related to risks reduction, reuse, inspection and repair and recycling, which appear to be significant benefits in addressing the problem of continuous improvement and sustainability.

For the calculation of the risks for individual stages of a chosen product cycle, we used the basic formula and processed the Register of comprehensive integrated environmental-safety and technical aspects, impacts and risks of the enterprise.

$\mathrm{Rp}_{\mathrm{n}}=\frac{\sum_{\mathrm{i}=1}^{\mathrm{a}} \mathrm{Ip}_{\mathrm{n}_{\mathrm{i}}} \times \mathrm{P} 1 \mathrm{p}_{\mathrm{n}_{\mathrm{i}}} \times \mathrm{P} 2 \mathrm{p}_{\mathrm{n}_{\mathrm{i}}}}{\mathrm{a}}$

\section{Explanation:}

$\mathrm{R}$ - Risk of individual stage of production of the product

$\mathrm{n} \quad$ - Number of stages, $\mathrm{n}=9$

$p_{n} \quad$ - Probability of the $n$-th production stage of the product

$I p_{n}$ - Importance of the $n$-th production stage

$P 1 p_{n}$ - Probability of the environmental impact of the n-th production stage of the product

$\mathrm{P} 2 \mathrm{p}_{\mathrm{n}}$ - Probability of the impact on human health of the n-th production stage of the product

a - Number of environmental-safety and technical aspects of the $n$-th stage production of the product

The greatest risk, as shown in Fig. 2, arises from handling of substances and materials in the warehouse because there are stored absorbents contaminated by pollutants, solvents, chemicals, plastic and metal containers, which, when handled improperly, can cause a risk of an adverse impact on the environment and human health.

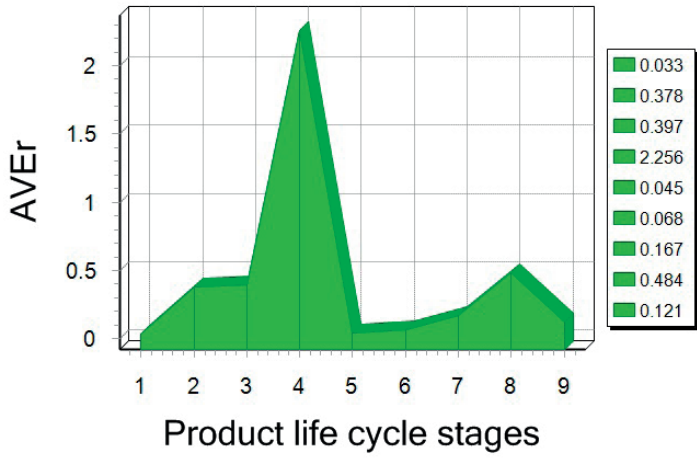

Legend:

1. Receipt of material

2. Transportation of the product to the warehouse

3. Transportation by forklift

4. Handling in the warehouse

5. Cutting the cables

6. Contact, welding, soldering, cutting contacts

7. Stripping of cables

8. Cable formation, repairs

9. Electrical control, packaging

AVEr - Average risk of an individual production stage of the product

Fig. 2 Evaluation of total environmental-safety and technical risks lifecycle production of cable harnesses

\section{Results and discussion on determination of the total value of environmental-safety and technical risks}

The basic objective in determining or calculation was to identify and prioritize the key for addressing the risks of life-cycle production of cable harnesses (handling in the warehouse) and generalize a new, more precise approach for their reuse also of other products in the industry.

The nature of the risk assessment is in the decision whether we can take the risk (see Table 2) and, if not, what measures we have to implement to eliminate the risk or at least to minimize it to an acceptable level. The total value of environmental-safety and technical risks for the automobile wiring harnesses product was $48 \%$, while it is shown that it is necessary to make improvements to minimize the environmental impact in the stage of material handling in the production of cable harnesses.

\begin{tabular}{|l|l|}
\hline Range of environmental-safety and technical risk & Evaluation of environmental-safety and technical risk \\
\hline R greater than $150 \%$ & Requires immediate action \\
\hline$R$ in the range of $75 \%-150 \%$ & Planned action according to the nature of danger \\
\hline$R$ to the extent of $15 \%-75 \%$ & Requires increased attention \\
\hline R smaller than $15 \%$ & Acceptable level \\
\hline
\end{tabular}




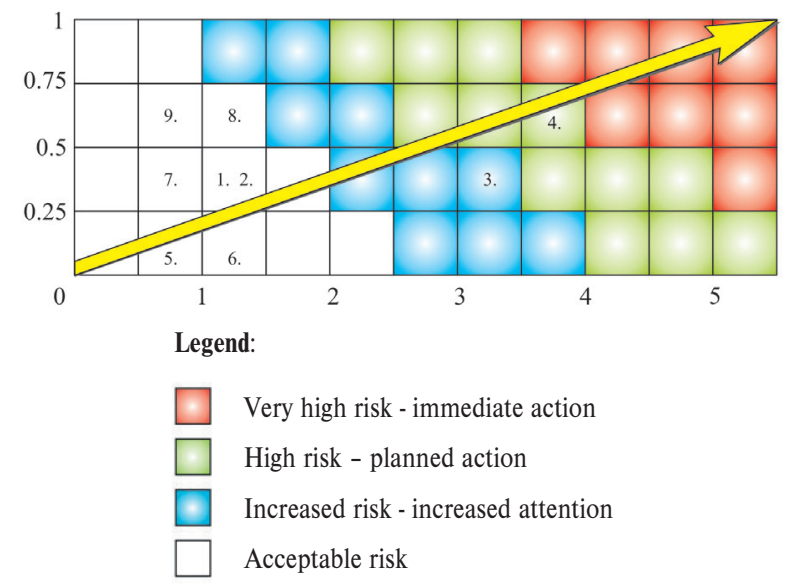

Fig. 3 Measurement of environmental-safety and technical risks

Environmental-safety and technical risks from various dangerous situations within the processes were transformed into a risk matrix (see Fig. 3). This way of formalization makes it easy to identify items which must be prioritized in the purposeful prevention of threats to life and working environment and workers' health. In the process of risk mapping as well as in the case of risk prioritization, two components will be used:

- probability of an impact,

- importance.

Probability of an impact will demonstrate a value determining uncertainty of occurrence of a specific event, phenomenon and severity, which will express a certain degree of deterioration. The prepared matrix, shown below, connects the seriousness of the risk and probability of the occurrence of environmental-safety and technical risks.

Effective prevention against damaging of health and the environment is based on the knowledge of the risk nature and their severity. The necessary condition of effective prevention is to meet all the requirements imposed by regulations and ISO standards OHSAS 18001 and/or ISO 14001. The determination of risk prevention measures is the result of all previous steps. The measures aim to eliminate the risks at the source of their origin or to mitigate them such that the risk to the environment and human health has been minimized.

The most effective method of prevention is to eliminate risks, for example, by a technological change and focus on the best available (BAT) changes in working practices, or increasing the distance from the source of a worker's risk, alternatively, other organizational arrangements. However, it is important not to allow the risk to be transferred to another place where the consequences of new arrangements could be even more serious.

If you cannot eliminate the risk by technical or technicalorganizational measures, or reduce it to an acceptable level at the source, technical collective protection measures are used.
For example, there are installed safety devices which turn off the work equipment when a worker enters dangerous zones, a suction device removing pollutants from the breathing zone and others.

In cases when you cannot use the previous measure or despite its use some risk remains, we use PPE (Personal Protective Equipment). At the same time organizational measures, taken to minimize a worker's exposure to that risk, are introduced.

A complex integrated assessment of relations between probable risk and its consequences on the environment and health of workers can also use a 3D diagram (see Fig. 4). This type of a diagram allows to put all three parameters into a mutual relation simultaneously.

The significance degree of a risk $\mathrm{R}$ is, in this case, determined by the product of the score of risk importance and probability of
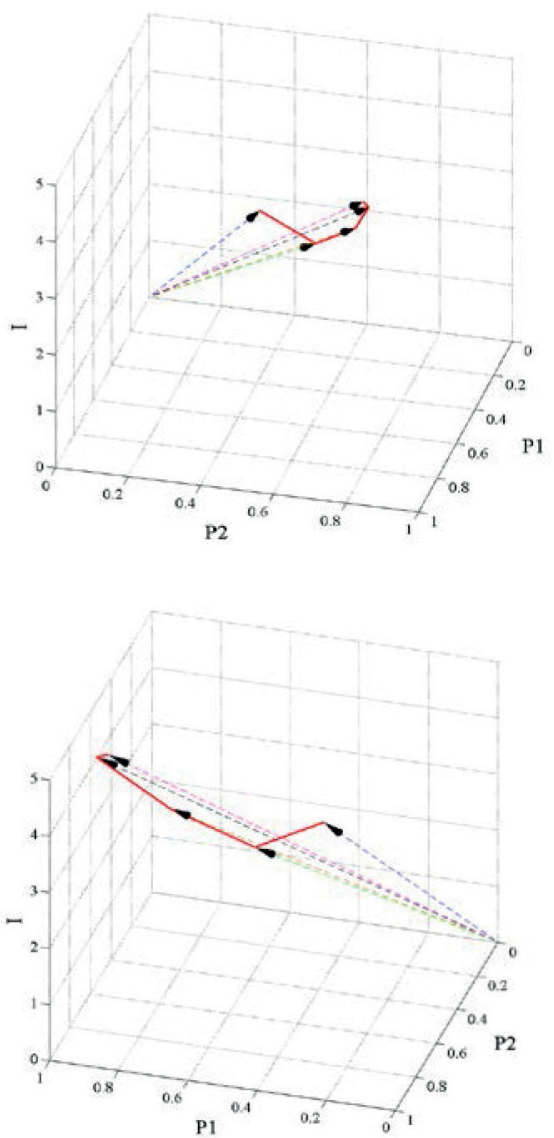

Legend:

$-\rightarrow$ Plastic containers containing residues of dangerous substances

$-\rightarrow$ Chemicals

$-\rightarrow$ Hazardous substances, solvents

$-\rightarrow$ Absorbents contaminated by pollutants

$-\rightarrow$ Metallic packaging

Fig. 4 Integrated assessments of environmental-safety and technical risks of production of cable harnesses 
the impact on the environment and probability of the impact on human health. The relationship is as follows:

$\mathrm{R}=\mathrm{I} \times \mathrm{P} 1 \times \mathrm{P} 2$

The value of the risk $\mathrm{R}$ importance degree may be in the range of $1 \%$ to $150 \%$. Also, in this case, the resulting numerical risk assessment and determination of the degree is influenced by subjective opinions, while unacceptable risk can be considered values greater than $75 \%$.

The risk assessment is a process ongoing in most cases separately, but it cannot be understood in isolation. The risk assessment is a part of risk management and it is a process for the implementation and use of which there is currently high demand.

The analysis and management of environmental-safety and technical risks aim to eliminate risks, although, we have to realize that their complete elimination is not possible. It is important to reduce the level of risk to an acceptable level. This level is reflected in the residual risk which is acceptable for the company, individual, organization. The results of the analysis of environmental-safety and technical risks have, from this point of view, a very significant importance, especially for the adoption of reasonable preventive solutions which are very important for health and safety and protection of human lives and working environment.

\section{Conclusion}

A more exact procedure for integrated management of environmental-safety and technical risks in the automobile industry supply company, using a cubic matrix diagram, was suggested and verified on a case study. It allows to express the risk more exactly and explore significant connections and relationships of environmental, safety and technical aspects, impacts and risks of production sorted according to their relevance in the integrated register.

The proposed methodological approach allows not only identifying risks, but also prioritizing them according to their relevance and the implementation of results within environmentalsafety management forming part of the integrated management system based on international standards and principles of a sustainable development.

Our research was primarily aimed on the identification of risks in an integrated 3D model which can be inspiring and helpful in identifying the main areas of risk occurrence and finding effective solutions to problematic issues. In further research methodology extended by examination of relevant socio-economic aspects, modified and implemented for a variety of products analyzed in the automotive industry and, ultimately, a methodology for the car as a whole may be proposed.

\section{References}

[1] JAYAL, A. D., BADURDEEN, F., DILLION, O. W. JR., JAWHIR, I. S.: Sustainable Manufacturing: Modelling and Optimization Challenges at the Product, Process and Systems Levels, CIRP - J. of Manufacturing Science and Technology, 2010, vol. 2, pp. 144-152.

[2] KAEBERNICK, H., KARA, S., SUN, M.: Sustainable Product Development and Manufacturing by Considering Environmental Requirements, Robotics and Computer Integrated Manufacturing, 2003, vol. 19, No. 6, pp. 461-468, DOI: 10.1016/S07365845(03)00056-5.

[3] KOTLER, P., CASLIONE, A. J.: Chaotes, Bratislava : Eastone Books, 2010, vol. 2, p. 168, ISBN 978-80-8109-114-8.

[4] KRAJNC, D., GLAVIC, P.: How to Compare Companies on Relevant Dimensions of Sustainability, Ecological Economics, 2005, vol. 55, No. 4, pp. 551-563.

[5] LABUSCHAGNE, C., BRENT, A. C., ERCK, R. P. G. V.: Assessing the Sustainability Performances of Industries, J. of Cleaner Production, 2005, vol.13, No. 4, pp. 373-385.

[6] LOVECEK, T.: Security System - Security of Information System, EDIS : University of Zilina, 2007, p. 246. ISBN 978-80-8070-767-5.

[7] POPE, J., ANNANDALE, D., SAUNDERS A. M.: Conceptualizing Sustainability Assessment, Environmental Impact Assessment Review, 2004, vol. 24, No. 6, pp. 595-616.

[8] RYBAROVA, D., GRISAKOVA, N.: Business Risk $1^{\text {st }}$ ed., Bratislava : Iura Edition, 2010, p.179. ISBN 978-80-8078-377-8. 